\title{
nature
}

29 July 2004 Volume 430 Issue no 6999

\section{Tribal culture versus genetics}

A dispute between researchers and a small Native American tribe has cast an unduly large shadow over genetics. Both sides have much to gain from deeper communication, aided by those who belong to both communities.

$\mathrm{N}$ ative Americans in the southwestern United States are in conflict with researchers over a genetics study. The Havasupai tribe has engaged scientists and universities in a legal battle over a diabetes research project. The tribe's lawsuits allege that researchers from Arizona State University and other institutions used DNA for studies without proper consent. The project's leader emphatically denies this, and researchers are stunned at the allegations about their (as they see them) benevolent efforts.

Politically charged interpretations of the dispute have spread through Native American communities, fanning tribal distrust of academics. Ill-founded rumours are the last thing that tribes and scientists need at this promising time for genomic research.

Such studies last for years, and the dispute highlights the importance of researchers keeping in constant communication with their Native American research subjects throughout (see page 500). History has shown that a court of law is not a good forum for resolving ethical debates. But how to balance the need for sensitivity to tribal culture while fostering rigorous scientific inquiry?

Some tribes now maintain their own human-subjects committees, which must approve all research projects. There are advisory committees to assist groups in monitoring projects whose complexities are difficult for non-scientists to understand. And there are proposals for Native American gene banks controlled and monitored by the tribes themselves - a concept that could provide them with ownership of products that may be derived from their genes.

All of these initiatives offer promising opportunities, but they also come with responsibilities for both researcher and subject. If subjects want to know what the researchers are trying to accomplish, and are kept informed, clashes of culture and science may be prevented.
Moreover, there have been a growing number of instances in which repeat consent was sought from research subjects from special communities, where language and cultural barriers may complicate projects. While worthy, this concept - time-consuming and potentially costly - would be unnecessary if there was a regular two-way flow of information between researchers and subjects.

Some ethicists suggest that an obsession with the details of consent have caused research subjects to forget they have an opportunity to help not only their own tribe, but all mankind. For Native Americans, this is a hard concept to accept. Having seen their people and cultures abused for centuries, they are understandably hypersensitive. But it could be a new form of empowerment for them to realize that their culture helped cure a disease.

Today, many Native American tribes have economic opportunities they never dreamed of, including education and access to scholarships. Gaming revenues provide better community services and chances to eliminate the sicknesses of poverty that for generations have plagued reservations. But too often this new-found economic clout is used to further litigation for tribal political purposes. In Arizona, sensitive, caring scientists are privately saying they do not want to go anywhere near a reservation after recent events in the Havasupai case. Given the broader potential benefits of research, this cannot be a climate that tribes wish to foster.

Leaders from both communities need to reach out to each other to bridge the gap between their cultures. The National Human Genome Research Institute is funding work to do precisely this. One group in a unique position to help are Native American scientists: they too can support dialogues to create a research environment to match the genetic opportunities of the times.

\section{States versus gases}

\section{A state-led lawsuit against greenhouse-gas emitters highlights a forceful regional movement in US climate policy.}

$\mathrm{f}$

f you had to predict who would save the world, city lawyers may not instantly spring to mind. So many people were surprised last week when US lawyers launched a strike against global warming.

Attorney-generals from eight states and lawyers from New York City filed a lawsuit demanding cuts in emissions from the five major power companies that they say belch out about $10 \%$ of the nation's carbon dioxide (see www.nature.com/news/2004/040719/ full/040719-12.html). The move is an unmistakable dig at the Bush administration for shirking strict curbs on greenhouse-gas emissions in favour of voluntary reductions.

Much of the lawsuit is sheer showmanship from the ambitious legal team behind it. When they get their day in court, they may struggle to win a guilty verdict. It may be tough to prove that a few companies should shoulder the blame for their share in a global problem, or that the modest cuts the lawsuit seeks would help.

But the trial signals that the fight against global warming in the United States is far from over. Lawyers and policy-makers in individual states are willing to take the issue into their own hands - even if
President George Bush is sitting on his. And the states can force the federal government to deal with issues where activists have failed.

The Regional Greenhouse Gas Initiative, for example, is an effort by nine northeastern and mid-Atlantic states to build a system to cap greenhouse-gas emissions. California, meanwhile, is developing legislation demanding curbs in carbon dioxide from vehicles. Such initiatives could drive a change in national policy simply by showing that it can be done, or because companies reined in by conflicting state laws may turn to the federal government for clarity.

Many environmentalists would like to see the heads of power plants squirm in the dock, and may get their wish. Some experts predict an imminent wave of lawsuits against greenhouse-gas producers, much like those against the tobacco industry, from people claiming damages for property or loved ones lost to floods or droughts.

But acrimonious court battles are not the best way to resolve issues that affect the future of the planet. Negotiation, legislation and regulation are. State lawmakers should unite and act where the federal government has not; scientists and activists should support them. 